\title{
METEOROLOGICAL DROUGHT ANALYSIS USING ARTIFICIAL NEURAL NETWORKS FOR BURSA CITY, TURKEY
}

\author{
KATIP, A. \\ Department of Environmental Engineering, Faculty of Engineering, Uludag University \\ Görükle Campus, 16059 Bursa, Turkey \\ e-mail:aballi@uludag.edu.tr \\ (Received 21 ${ }^{\text {st }}$ Feb 2018; accepted $24^{\text {th }}$ May 2018)
}

\begin{abstract}
Climate change is one of the most important environmental events of recent years. Floods and droughts may occur more frequently with climate change. Droughts could be classified as meteorological, hydrological or agricultural. When meteorological drought appears in a region, agricultural and hydrological droughts follow. In this study, the standardized precipitation index (SPI) was applied for meteorological drought analysis in Bursa City-Turkey. Analyses were performed on 3-, 6-, 9- and 12-month-long data sets. According to the analyses most of the percentages (67-72\%) for all SPI values $(3,6,9,12$ months) was in the near normal class close to Marmara Region-Turkey. Also meteorological variables and SPI-12 values were simulated with ANN models and had different structures. It was found that R and MSE values calculated were in the acceptable ranges and rising of hidden layers and input numbers in the model structures was ensured for more efficient model run. Modelling the precipitation from the meteorological parameters (Model 2) was possible with some error. Therefore simulations of SPI-12 and soil temperatures were indicative to meteorological and agricultural droughts. Comparison of the observed values and the modelling results showed a better agreement with SPI-12 and soil temperature parameters. Drought predictions made by ANN models would be useful for local administrations and water resources planners and would be extremely important for drought risk management.
\end{abstract}

Keywords: aridness, standardized precipitation index (spi), modelling

\section{Introduction}

In an increasing and demanding society with the development of industrial technology, mineral and energy resources are needed for fossil fuels. Besides the obvious benefits (rising of the living standards for most people) the exploitation of the natural resources of the Earth has not been without a cost. This cost is climate change. Climate change refers to both the rise in global temperatures because of human activities and the many consequential impacts such as more intense and frequent droughts and storms, melting glaciers and ice sheets, rising sea levels, warming seas (NOAA, 2017).

Droughts naturally occur in almost all climatic zones, and are a result of the reduction of precipitation from normal amounts for an extended period of time (Belayneh et al., 2016). Precipitation is not the only factor determining the development of drought. Hot weather, low soil moisture, wind, increasing demand of water due to population growth, irregular usage of water resources and human activities in the regions influence the drought events. Extended periods of drought can lead to several adverse consequences, which include a disruption of the water supply, low agricultural yields, and reduced flows for ecosystems (Belayneh et al., 2016). As the result of the long meteorological drought, agricultural and hydrological drought occurs. Drought may cause famine, hunger, and death and so it affects a community socially, economically and psychologically. Water shortages will become one of the most important environmental and social problems in some countries around the world in the near future (IPCC, 2014). 
Annual water amount per capita in Turkey is expected to decline $\left(700-1910 \mathrm{~m}^{3}\right)$. Increasing evaporation because of global climate change will cause occurrence of more severe and prolonged droughts in Turkey (Kurnaz, 2014). Variation in the hydrological cycle will conduce to irrigation and water supply problems as well as increase in sudden flood events (Wen et al., 2013). Therefore, drought analysis is important in water resource management and planning, and for long-term economic and social planning (Buttafuoco and Caloiero, 2014; Ibrahimi and Baali, 2017).

Forecasting and analyzing meteorological drought characteristics specifically their initiation, time, frequency, severity and involved area are important. Because time, duration and severity of drought are not known it is analyzed with probability and statistical methods in any region (Belayneh et al., 2016; Deo et al., 2015; Ibrahimi and Baali, 2017; Buttafuoco and Caloiero, 2014). Precautions could be taken to minimize the drought with drought analysis and measures. Drought can be examined spatially and temporally. When the temporal analyses were made, duration, amplitude and intensity of drought might be calculated.

A drought period starts when the Precipitation Index falls below zero. When the drought period finishes the Precipitation Index rises above this level. Number of drought periods are denoted as "m"; duration of drought periods are showed as $\mathrm{L}_{1}, \mathrm{~L}_{2}$, ........ $\mathrm{L}_{\mathrm{m}}$; total of lacks lower from each drought level-magnitude demonstrated as " $\mathrm{M}_{1}$, $\mathrm{M}_{2}, \ldots \ldots . . . \mathrm{M}_{\mathrm{m}} "$.

The ratio of magnitude to duration of drought periods is identified as "drought intensity" (McKee, et al., 1993). It is formulated as Equation 1:

$$
I_{n}=\frac{M_{n}}{L_{n}}
$$

The sum of the lack of $\mathrm{n}^{\text {th }}$ along a series $\mathrm{M}_{\mathrm{n}}$ (Magnitude) is calculated as Equation 2:

$$
M_{n}=\sum_{i=1}^{m}\left|X_{0}-X_{i}\right|
$$

In this equation:

$\mathrm{X}_{0}$ : SPI cutoff level is zero for each drought,

$\mathrm{X}_{\mathrm{i}}$ : It is a standardized series,

$\mathrm{m}$ : Number of drought periods for the cutoff level $\left(\mathrm{X}_{0}\right)$.

Maximum and minimum values of drought features $\left(\mathrm{L}_{\max }, \mathrm{L}_{\min }, \mathrm{M}_{\max }, \mathrm{M}_{\min }, \mathrm{I}_{\max }\right.$ and $\left.I_{\min }\right)$ are calculated for each cutoff level. Also, some basic statistical parameters as mean, standard deviation, median, skewness, kurtosis values are determined. These values inform about the statistical properties of the $\mathrm{M}, \mathrm{L}$ and I values of data set (McKee et al., 1993).

A common tool utilized to monitor current drought conditions is a drought index. Drought indices are expressed by a numeric number, which is believed to be far more functional than raw data during decision-making (Pedro-Monzonís et al., 2015). Several drought indices have been developed around the world in the past based on rainfall as the single variable, including the widely used Deciles. There are some indices as Standardized Precipitation Index (SPI) (McKee et al., 1993) and Effective Drought Index (EDI) (Deo et al., 2015) and also the well-known Palmer Drought Severity Index 
(PDSI) which considers temperature along with rainfall (Belayneh et al., 2016). In temporal and spatial drought analysis, standard precipitation index and kriging methods are generally used respectively. SPI (Eq. 3) obtained by precipitation (mm) at a given time is subtracted from the mean precipitation and in the sequel divided by standard deviation value (Anonymous, 2014a, 2016a).

$$
S P I=\frac{X_{i}-X_{i}^{\text {mean }}}{\sigma}
$$

In this equation:

SPI: Standard Precipitation Index

$X_{i}:$ precipitation $(\mathrm{mm})$

$X_{i}^{\text {mean }}:$ mean Precipitation (mm)

\section{$\sigma:$ Standard deviation}

The SPI drought index was chosen to forecast drought in this study due to its simplicity, its ability to represent droughts on multiple time scales, and because it is a probabilistic drought index. In addition, the study by Gürler (2017) determined that the SPI is the most appropriate index for monitoring the variability of droughts in Turkey because it is easily adapted to local climate, has modest data requirements, and can be computed at almost any time scale.

Application of statistical models has a long history in drought forecasting. Development of ANN (Artifical Neural Network) approaches with high precision of estimation was considered to be effective in eliminating the arduous task of field works and development of complex models that involve partial differential equations.

An application of ANN to solve civil and environmental engineering problems began in the late 1980s (Ibrahimi and Baali, 2017). ANN has recently been applied in hydrological forecasting to examine the rainfall-runoff relationship in watershed, to characterize daily stream flow and monthly reservoir inflow, to evaluate rainfall-runoff models, to forecast river flow, to forecast future precipitation values and for the purposes of drought forecasting (Daliakopoulos and Tsanis, 2016; Lima, et al., 2016; Pedro-Monzonís, et al., 2015; Belayneh et al., 2016). Also it could be used easily in climate models of catchment area (Salami and Ehteshami, 2016), forecasting for ecology, water quality and quantity (Sinha and Das, 2015; Lallahem and Hani, 2017; Chen et al., 2017)

In this paper, Standardized Precipitation Index-SPI (3, 6, 9, 12 months) were calculated based on monthly mean precipitation values, to determine drought categories and then total of 6 model structures were tested and validated with ANN model structures. The first aim of this paper was to develop suitable ANN models by considering the feed-forward back-propagation learning algorithm in the estimation of total monthly precipitation $(\mathrm{mm})$, the average monthly minimum and surface soil temperatures $\left(10 \mathrm{~cm},{ }^{\circ} \mathrm{C}\right)$ and SPI-12 values. The second aim was providing information from modeled parameters to meteorological and agricultural drought. Also the suitability of soil temperatures modelling for drought forecasting was investigated when the precipitation data was absent. For this purposes meteorological drought analysis was performed for the Bursa Centrum Station. In the drought analysis, it was determined that whether precipitation values were fitting gamma distribution and SPI method was used. Drought was investigated in SPI-12 and the obtained drought categories given by 
McKee et al. (1993) were modeled by ANN. Importance of this study lies in the risk management in countries around the world fighting with drought.

\section{Materials and methods}

\section{Study area and data}

Bursa is a large city in Turkey, located in Northwestern Anatolia, within the Marmara Region. It is the fourth most populous city in Turkey and one of the most industrialized metropolitan centers in the country. According to the 2013 general population determination results Bursa Province had 2,787,539 inhabitants (Anonymous, 2014b). Bursa between 28-30 degrees latitude and 40 degrees longitude circle is located in the southeast of the Marmara Sea (Fig. 1).

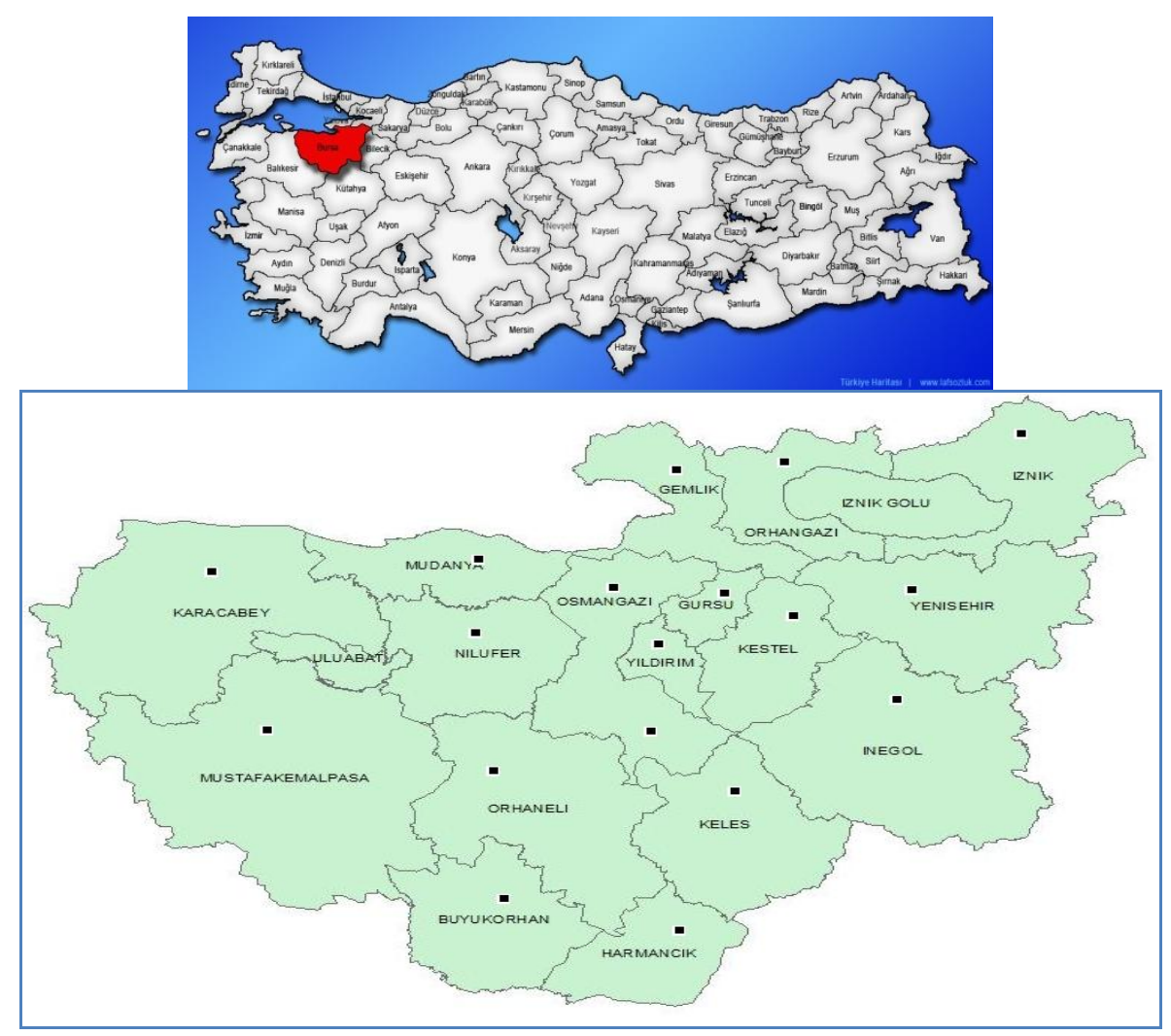

Figure 1. Location of Bursa City and Meteorology Station

It is $155 \mathrm{~m}$ above sea level and its total area is $10819 \mathrm{~km}^{2}$. The climate type of Marmara is dominant in Bursa. Marmara climate is known as a Terrestrial to Mediterranean transitional climate. Characteristics of the Marmara climate are as follows: annual precipitation is between $500-1000 \mathrm{~mm}$, annual average temperature values are $14-16{ }^{\circ} \mathrm{C}$, warmest month average: $23-25{ }^{\circ} \mathrm{C}$, coldest month average: $5-6{ }^{\circ} \mathrm{C}$. The most rain falls in winter, December, January, February. The arid months are June, July and August. Percent of precipitations are 38.3\% of winter, 9.4\% summer, $26.8 \%$ autumn and $25.5 \%$ in spring (Anonymous, 2014c). According to the long-term (19842013) averages, highest monthly average temperature was in July with $25.1{ }^{\circ} \mathrm{C}$, the lowest monthly average temperature was in January with $5.6^{\circ} \mathrm{C}$ and monthly average of 
the most rainfall was in December with $93.81 / \mathrm{m}^{2}$ (Boz, 2015). There are 16 meteorological stations in districts of Bursa City. There are no stations in Y1ldirım and Gürsu districts but two stations in the Osmangazi District. In this study, meteorological data (years of 1984-2013) from the 16 stations in Bursa was taken from Ministry of Forestry and Water Affairs, Meteorological Department Station 17116 (Bursa-Center) and meteorological drought was investigated. Between 12 and 40 station numbers were used for meteorological and agricultural drought analyses in many studies (Milanović et al., 2014; Sun et al., 2017; Łabędzki and Bak, 2017; Pablos et al., 2017). The stations are not located in district centers but in areas close to agricultural land. Therefore urban heat island could not cause significant difference between surface temperature in stations and in arable lands (Yang et al., 2016). The data collection was synoptic (3 hourly) and daily (Anonymous, 2014c). Reporting periods for long-term averages according to climatological standard were either 1971-2000, or 1981-2010. But the climatological values between different date ranges in the international reports were presented and evaluated (NOAA, 2017). Regular data recording for Bursa stations had started in 1984. Thus, the values between 1984 and 2013 were evaluated in this study. The parameters for statistical calculations were monthly total precipitation $(\mathrm{mm})$, average air and soil temperature, pressure, vapor pressure, insolation intensity, wind speed, relative humidity were given in Table 1. Also long time averages of air temperature and monthly total precipitation are shown in Figures 2 and 3, respectively.

Table 1. Statistical values of used parameters (1984-2013)

\begin{tabular}{|c|c|c|c|c|c|c|}
\hline Parameters & Max & Min & Average & $\begin{array}{l}\text { Standard } \\
\text { deviation }\end{array}$ & Total* & $\% *$ \\
\hline $\begin{array}{l}\text { Monthly average air } \\
\text { temperature }\left({ }^{\circ} \mathrm{C}\right)\end{array}$ & 27.90 & 1.10 & 14.70 & 7.27 & 3 & 0.80 \\
\hline $\begin{array}{c}\text { Monthly average maximum air } \\
\text { temperature }\left({ }^{\circ} \mathrm{C}\right)\end{array}$ & 31.90 & 6.20 & 21.58 & 5.79 & 2 & 0.55 \\
\hline $\begin{array}{c}\text { Monthly average minimum air } \\
\text { temperature }\left({ }^{\circ} \mathrm{C}\right)\end{array}$ & 24.50 & -8.80 & 8.81 & 8.08 & 3 & 0.83 \\
\hline $\begin{array}{c}\text { Monthly average minimum } \\
\text { surface soil temperature }\left({ }^{\circ} \mathrm{C}\right)\end{array}$ & 20.80 & -5.50 & 7.47 & 5.89 & 17 & 4.72 \\
\hline $\begin{array}{l}\text { Monthly average } 10 \mathrm{~cm} \text { soil } \\
\text { temperature }\left({ }^{\circ} \mathrm{C}\right)\end{array}$ & 33.30 & 2.20 & 16.56 & 8.93 & 9 & 2.50 \\
\hline $\begin{array}{l}\text { Monthly total precipitation } \\
\text { (mm) }\end{array}$ & 396.60 & 0.00 & 58.26 & 48.26 & 3 & 0.83 \\
\hline $\begin{array}{c}\text { Monthly average pressure } \\
(\mathrm{hPa})\end{array}$ & 1017.00 & 997.50 & 1004.31 & 3.72 & 5 & 1.39 \\
\hline $\begin{array}{l}\text { Monthly average vapor } \\
\text { pressure }(\mathrm{hPa})\end{array}$ & 51.80 & 4.60 & 11.64 & 4.87 & 19 & 5.28 \\
\hline $\begin{array}{c}\text { Monthly average-daily total } \\
\text { global insolation intensity } \\
\left(\mathrm{cal} / \mathrm{cm}^{2}\right)\end{array}$ & 644.70 & 86.20 & 312.67 & 149.29 & 9 & 2.50 \\
\hline $\begin{array}{c}\text { Monthly total global insolution } \\
\text { intensity }\left(\mathrm{cal} / \mathrm{cm}^{2}\right)\end{array}$ & 19341.60 & 2585.25 & 9484.77 & 4578.44 & 9 & 2.50 \\
\hline $\begin{array}{c}\text { Monthly average wind speed } \\
(\mathrm{m} / \mathrm{s})\end{array}$ & 3.50 & 0.80 & 1.95 & 0.44 & 11 & 3.06 \\
\hline $\begin{array}{c}\text { Monthly average relative } \\
\text { humidity }(\%)\end{array}$ & 84.50 & 46.30 & 66.68 & 7.64 & 4 & 1.11 \\
\hline
\end{tabular}




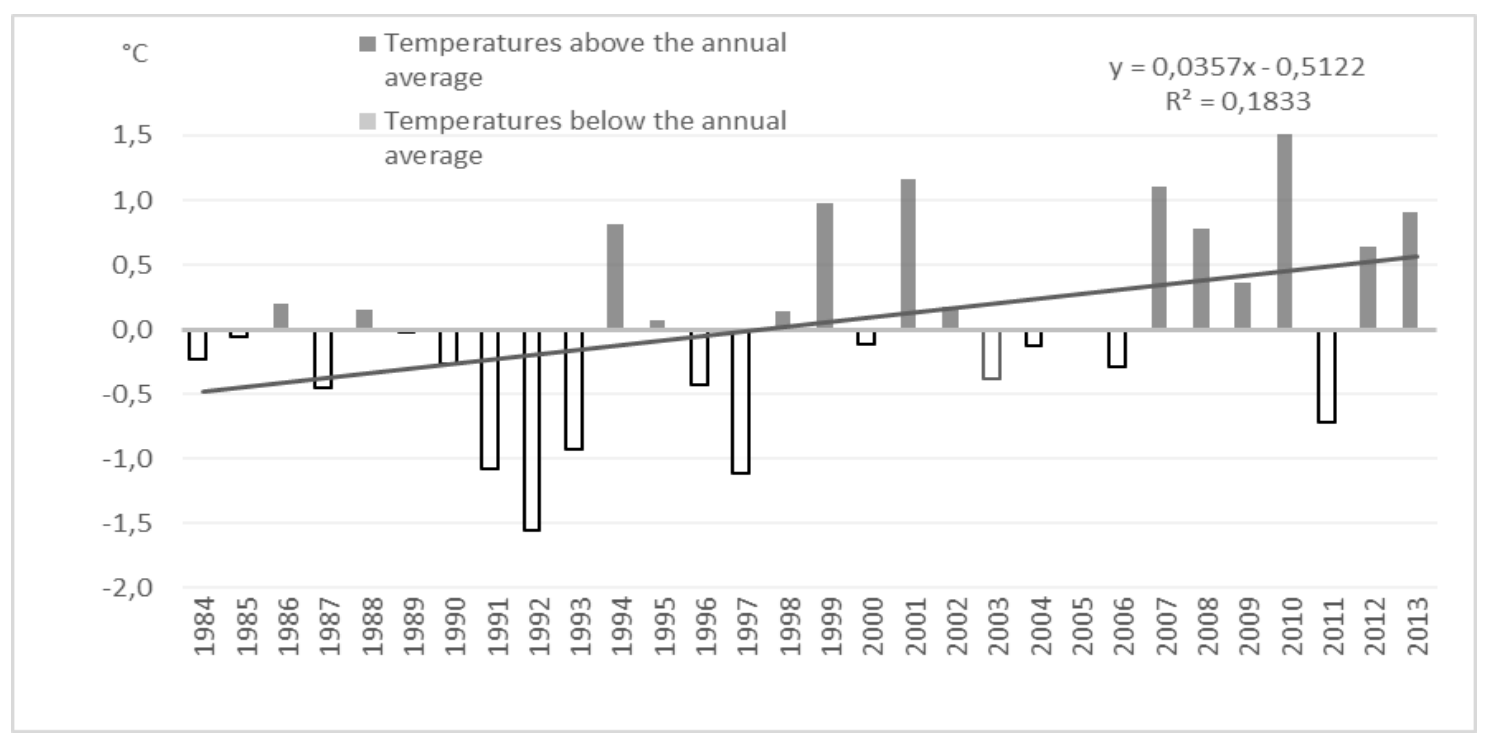

Figure 2. Long-time averages of air temperature

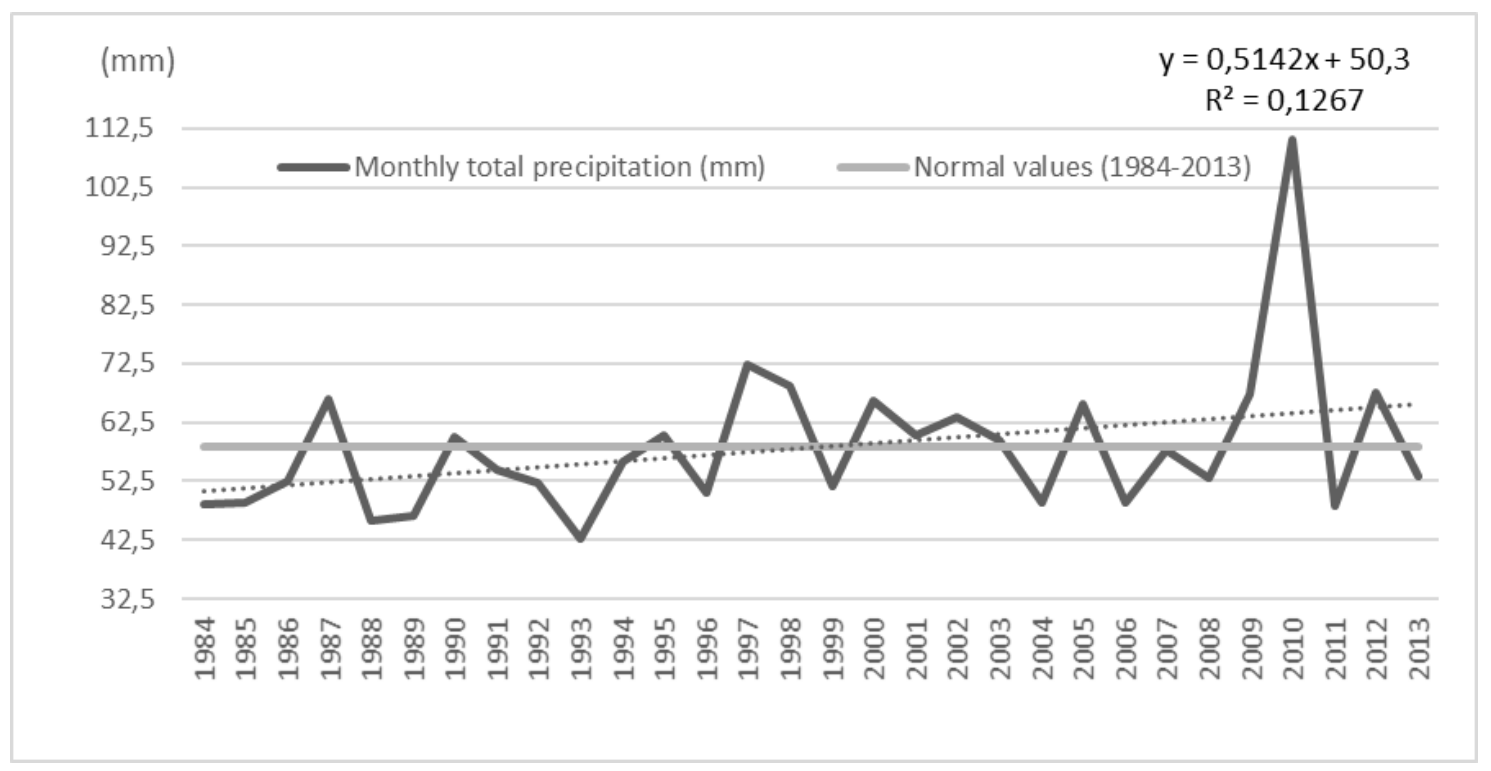

Figure 3. Long-time averages of monthly total precipitation

\section{SPI calculation}

The SPI is based on the probability of precipitation at any time scale (at least 30 years). The probability of observed precipitation is then transformed into an index. This long-term precipitation time series is then fitted to a gamma distribution, which is then transformed through an equal probability transformation into a normal distribution. Positive SPI values indicate wet conditions with greater than median precipitation and negative SPI values indicate dry conditions with lower than median precipitation. McKee and others (1993) originally calculated the SPI for 3-, 6-, 12-, 24- and 48-month timescales (Buttafuoco and Caloiero, 2014; Belayneh et al., 2016; Anonymous, 2016a). Table 2 presents SPI drought classes. 
Table 2. SPI drought classification (Anonymous, 2016a)

\begin{tabular}{c|c}
\hline SPI Values & Class \\
\hline$>2$ & Extremely wet \\
$1.5-1.99$ & Very wet \\
$1.0-1.49$ & Moderately wet \\
-0.99 to 0.99 & Near normal \\
-1 to -1.49 & Moderately dry \\
-1.5 to -1.99 & Very dry \\
$<-2$ & Extremely dry \\
\hline
\end{tabular}

In order to calculate the SPI, a probability density function that adequately describes the precipitation data must be determined. The gamma distribution function was selected to fit the raw rainfall data in this study. The SPI is a $z$-score and represents an event departure from the mean, expressed in standard deviation units. The SPI is a normalized index in time. SPI values can be categorized according to the classes.

In this study, the SPI_SL_6.exe (Standardized Precipitation Index Program) was compiled in $\mathrm{C}++$ for $\mathrm{PC}$ developed by the National Drought Mitigation Centre, University of Nebraska-Lincoln, and it was used to compute time series of drought indices (SPI) for the station in the Bursa and for each month of the year at different time scales (Anonymous, 2016a). The input file was set up to analyse the 1-, 3-, 6-, 9- and 12-month SPIs and output file of the months was constituted.

In this study, input and output data for the simulations were normalized SPI values depending on precipitation. Before the training SPI values were demeaned 0 to 1 . So variables were made dimensionless and similarity selected at random has been removed.

The formulation for dimensionless (normalization) values was determined with Equation 4:

$$
F=\left(F_{i}-F_{\min }\right) /\left(F_{\max }-F_{\min }\right)
$$

In this equation, $\mathrm{F}$ was any dimensionless value; $\mathrm{F}_{\mathrm{i}}$ was $i^{\text {th }}$ value in measurements; $\mathrm{F}_{\max }$ and $F_{\min }$ were maximum and minimum measurements (Ibrahimi and Baali, 2017; Deo et al., 2015).

\section{ANN model and training algorithm}

Artificial neural networks are formed of a set of simple elements, the alleged artificial neurons. These elements are inspired by biological nervous systems. Models of neural networks are separated into two categories: feed forward neural networks and recurrent neural networks. Feed forward neural networks deliver data linearly from input to output and they are the most popular and most widely used models in many practical applications (Daliakopoulos and Tsanis, 2016). The feed forward neural network (FNN) with as few as a single hidden layer and arbitrary bounded and smooth activation functions can approximate a continuous nonlinear function. The model of a neuron and multi-layer FNN is represented in Figure 4 (Chen et al., 2014; Yonar and Yalı1, 2014). 


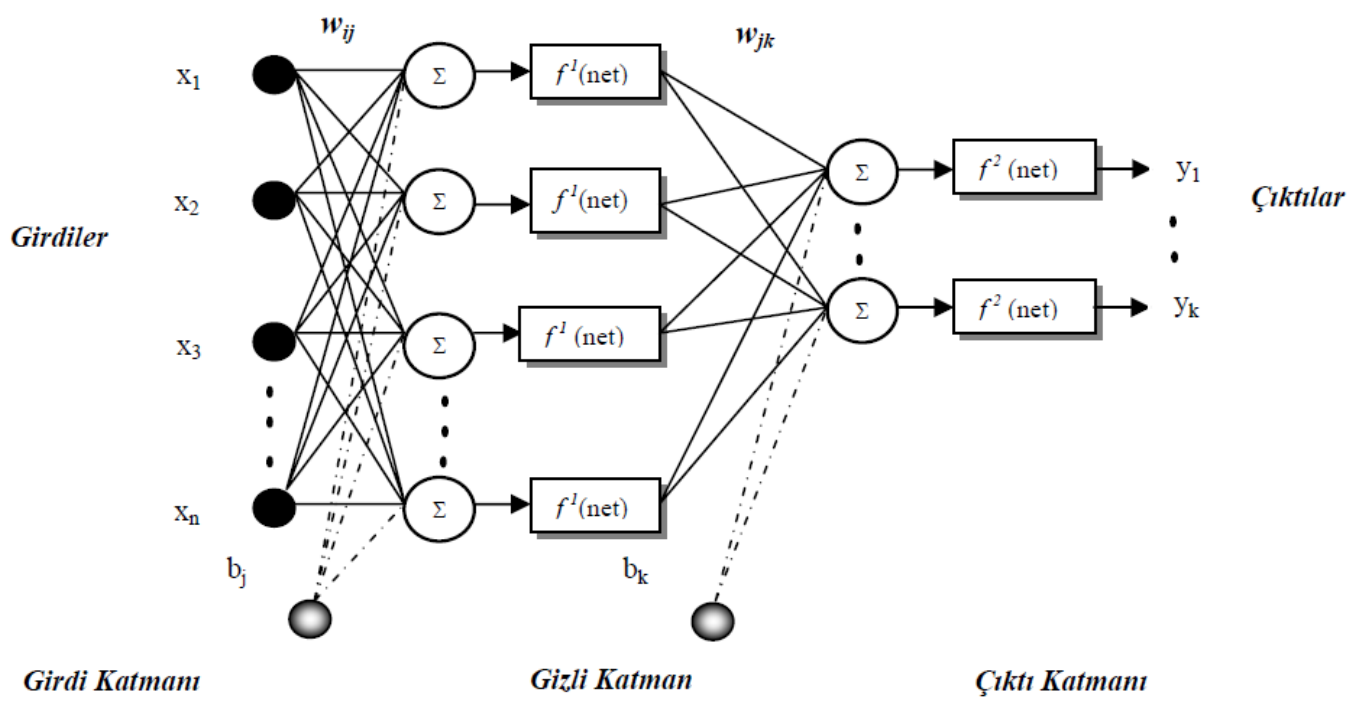

Figure 4. Multi-layer feed forward neural network

As shown in Figure 4, the elements constituting ANN are input layers, hidden layers (number of hidden layers are one or might be more\}, output layer linkages between the layers and linkage weights.

The data of the problem is in the input and output layers. Productivity and importance of information in the input layer are provided with the weights. Net (basis) function expresses that effectiveness of input data to neuron. For an analytical study, the connection networks are mathematically represented by a basis function $\mathrm{u}(\mathrm{w}, \mathrm{x})$. The net value is a linear combination of the inputs and the output of a neuron can be expressed as Equation 5:

$$
\text { out }=f(n)
$$

where

$$
n=\sum_{j=1}^{R} w_{j} x_{J}+b
$$

$\mathrm{x}_{1}, \mathrm{x}_{2}, \ldots, \mathrm{x}_{\mathrm{R}}$ are the input signals; $\omega_{1}, \omega_{2}, \ldots, \omega_{\mathrm{R}}$ are the weights of neuron; $\mathrm{b}$ is bias value; and $\mathrm{f}(\cdot)$ is the activation function.

Activation function is a function determining the neuron output with processing the net inputs obtained from net function. The linear and sigmoid are common used activation functions in the construction of artificial neural networks.

An example of the sigmoid is the logistic function, defined by Equation 6:

$$
f(n)=\frac{1}{1+e^{-n}}
$$

As sigmoid function (Eq. 7) can also be used as hyperbolic tangent function and it gives the outputs range between [0-1] (Cömert and Kocamaz, 2017): 


$$
f(n)=\frac{1-e^{-n}}{1+e^{-n}}
$$

The inputs $\mathrm{x}_{1}, \mathrm{x}_{2}, \ldots, \mathrm{x}_{\mathrm{R}}$ are multiplied by weights $\omega_{\mathrm{i}}, \mathrm{j}_{(1)}$ and summed at each hidden neuron i.

Then the summed signal would be calculated as Equation 8:

$$
n_{i(1)}=\sum_{j=1}^{R} w_{i, j(1)} x_{J}+b_{i(1)}
$$

The output y at a linear output node can be calculated as Equation 9:

$$
y=\sum_{i=1}^{z} w_{1, i(2)} \frac{1-e^{-\left(\sum_{i=1}^{R} x_{j} w_{i, j(1)}+b_{i(1)}\right)}}{1-e^{-\left(\sum_{i=1}^{R} x_{j} w_{i, j(1)}+b_{i(1)}\right)}}+b_{1(2)}
$$

where $\mathrm{R}$ is the number of inputs, $\mathrm{z}$ is the number of hidden neurons, wi.j(1) is the first layer weight between the input $\mathrm{j}$ and the $\mathrm{i}^{\text {th }}$ hidden neuron, $\omega 1, \mathrm{i}(2)$ is the second layer weight between the $\mathrm{i}^{\text {th }}$ hidden neuron and output neuron, bi(1) is a biased weight for the ith hidden neuron and b1(2) is a biased weight for the output neuron (Chen et al., 2014)

The learning algorithms using in ANN are heuristics, partial Newton methods, matched gradient methods and Levenberg Marquardt methods. In this study feed forward neural network structure was used and Levenberg Marquardt training algorithm supervised training algorithms was preferred for training. Levenberg Marquardt algorithm is the least squares calculation method based on maximum neighborly idea (Chen et al., 2017). The sum of squared errors of any one of the element in the training set ( $\mathrm{N}$ number of elements) could be calculated as Equation 10:

$$
E(w)=\frac{1}{2} \sum_{i=1}^{N}\left(y_{m i}-y_{i}\right)^{2}=\frac{1}{2}\left(y_{m}-y\right)^{T}\left(y_{m}-y\right)
$$

Symbol (w) in Equation 10 would be defined as Equation 11:

$$
w=\left[w_{1,1(1)}, w_{1,2(1)}, \ldots, w_{z, R(1)}, b_{1(1)}, b_{2(1)}, \ldots, b_{z(1)}, w_{1,1(2)}, w_{1,2(2)}, \ldots, w_{1, z(2)}, b_{1(2}\right.
$$

Two number of different hidden layer neuron for each input neurons was tested in this study. This was because; in the recent study were two different approaches used in determining the number of hidden layer neurons. The first was $(\mathrm{N}+1) / 2$ and the second one was $(2 * \mathrm{~N}+1)($ Chen et al., 2017). "N" was the number of neuron in the input layer (Chen et al., 2017).

\section{Performance and sensitivity analysis of ANN}

The performance of the forecasts from the data-driven models was evaluated. The Pearson correlation coefficient is one of the most commonly used performance in selecting proper inputs for the ANN (Chen et al., 2014). Correlation coefficient is 
described as the degree of correlation between the empirical and modeled values (Eq. 12):

$$
r=\frac{\sum_{i=1}^{N_{0}}\left(y_{i}-\bar{y}\right)\left(y_{m i}-\bar{y}_{m}\right)}{\sqrt{\sum_{i=1}^{N_{0}}\left(y_{i}-\bar{y}\right)^{2}} \sum_{i=1}^{N_{0}}\left(y_{m i}-\bar{y}_{x}\right.}
$$

where $y_{i}$ and $y_{m i}$ enounce the network output and measured value from the $i^{\text {th }}$ element; $\bar{y}$ and $\bar{y}_{\mathrm{m}}$ conceive their average respectively, and $\mathrm{N}_{\mathrm{o}}$ describes the number of measurements.

Another performance computation is mean absolute error (MAE). The MAE is used to measure how close forecasted values are to the observed values. It is the average of the absolute errors. The smaller values of MAE and MSE (mean square error) provide the better performance (Belayneh et al., 2016). MAE and MSE are estimated with Equations 13 and 14:

$$
\begin{aligned}
& M A E=\frac{1}{N_{0}} \sum_{i=1}^{N_{0}}\left|y_{m i}-y_{i}\right|^{2} \\
& M S E=\frac{1}{N_{0}} \sum_{i=1}^{N_{0}}\left(y_{m i}-y_{i}\right)^{2}
\end{aligned}
$$

\section{ANN application}

In this study, all the ANN models were created with the MATLAB ANN toolbox (Matlab, 2015). The tangent sigmoid transfer function was the activation function for the hidden layer, while the activation function for the output layer was a linear function. All the ANN models in this study were trained using the Levenberg Marquardt (LM) back propagation algorithm. The LM back propagation algorithm was chosen because of its efficiency (Nawi et al., 2016; Cömert and Kocamaz, 2017).

All the ANN models the cross validation technique was used to partition the data sets; $80 \%$ of the data was used to train the models, while the remaining $20 \%$ of the data was used to test and validate the models, with $10 \%$ used for testing and $10 \%$ used for validation (Berhan et al., 2015; Belayneh et al., 2016). The training set was used to compute the error gradient and to update the network weights and biases. The error from the validation set was used to monitor the training process. If the network over fits the data the error in the validation set will begin rising. The testing data set is an independent data set and is used to verify the performance of the model.

Total number of 359 data based on monthly average values was used in this study and 6 model structures were tried. In the first model 6 parameters associated with air temperature, global insolation and precipitation parameters were used as inputs, the parameters of monthly average of $10 \mathrm{~cm}$ soil depth temperature and monthly average of surface soil minimum temperature were outputs. In the second model, 3 numbers of air temperature, 2 of soil temperature, 2 number of global insolation and monthly average of humidity parameters were used as inputs (total of the 8 parameters) and monthly total precipitation parameter was identified as output. 3 and 9 month SPI values in 3rd and 4th models and 3,9 and 12 month SPI values in 5th and 6th models were used as input 
parameters. 12 month SPI was defined as output in3rd, 4th, 5th and 6th models. In the 1st and 2nd models, only meteorological parameters were modeled. SPI parameters were modeled in the other 4 models. The results related to ANN modelling experiments with a different number of hidden layers were defined in a comparative way.

\section{Results and discussion}

\section{Assessment of SPI Values}

3, 6, 9 and 12 month SPIs were calculated with SPI_SL_6.exe program. If the Standard Precipitation Index falls below zero a drought period start, number of drought periods " $m$ ", duration of drought periods $\mathrm{L}_{1}, \mathrm{~L}_{2}, \ldots \ldots . \mathrm{L}_{\mathrm{m}}$ and total of lack from each drought level-Magnitude " $\mathrm{M}_{1}, \mathrm{M}_{2}, \ldots . . . \mathrm{M}_{\mathrm{m}}$ " and the ratio of magnitude to duration of drought periods identified as "drought intensity" parameters were calculated with Microsoft Office Excel (Windows 7 Home Premium) computer program. In addition to this cutting levels were decided as class intervals for SPI. According to the cutting levels $\mathrm{M}, \mathrm{L}$ and I values were obtained for mild, moderate, severe and extreme drought conditions. The calculated statistical parameters of drought were given in Table 3.

Table 3. The statistical parameters of drought

\begin{tabular}{|c|c|c|c|c|c|c|c|c|c|c|}
\hline \multicolumn{2}{|c|}{$\begin{array}{c}\text { Drought } \\
\text { parameters }\end{array}$} & \multirow{2}{*}{\begin{tabular}{|c|}
$\begin{array}{c}\text { Number } \\
\text { of events }\end{array}$ \\
50
\end{tabular}} & \multirow{2}{*}{$\frac{\text { Max }}{13}$} & \multirow{2}{*}{$\frac{\text { Min }}{1}$} & \multirow{2}{*}{$\begin{array}{c}\text { Median } \\
3\end{array}$} & \multirow{2}{*}{\begin{tabular}{c|}
$\begin{array}{c}\text { Most of } \\
\text { repetition }\end{array}$ \\
1.00
\end{tabular}} & \multirow{2}{*}{$\frac{\text { Std }}{2.64}$} & \multirow{2}{*}{\begin{tabular}{|c|} 
Skewness \\
1.46
\end{tabular}} & \multirow{2}{*}{\begin{tabular}{|c|} 
Kurtosis \\
2.40
\end{tabular}} & \multirow{2}{*}{$\begin{array}{c}\text { Average } \\
3.460\end{array}$} \\
\hline & 3 Month & & & & & & & & & \\
\hline \multirow{3}{*}{$\mathbf{M}$} & 6 Month & 33 & 21 & 1 & 4.00 & 1.00 & 5.23 & 1.63 & 2.57 & 5.485 \\
\hline & 9 Month & 27 & 24 & 1 & 4.00 & 1.00 & 6.42 & 1.35 & 1.47 & 6.481 \\
\hline & 12 Month & 20 & 33.0 & 1 & 4.5 & 1.00 & 10.32 & 1.34 & 0.60 & 8.850 \\
\hline \multirow{4}{*}{$\mathbf{L}$} & 3 Month & 50 & 13.41 & 0.02 & 2.065 & 0.05 & 2.80 & 1.54 & 3.30 & 2.861 \\
\hline & 6 Month & 33 & 24.59 & 0.01 & 2.07 & - & 5.73 & 2.05 & 4.41 & 4.395 \\
\hline & 9 Month & 27 & 25.86 & 0.07 & 2.04 & 1.42 & 6.90 & 1.63 & 2.15 & 5.322 \\
\hline & 12 Month & 20 & 30.87 & 0.09 & 1.7 & - & 10.35 & 1.59 & 1.27 & 7.065 \\
\hline \multirow{4}{*}{$\mathbf{I}$} & 3 Month & 50 & 2.094 & 0.02 & 0.68 & 0.05 & 0.50 & 0.84 & 0.49 & 0.741 \\
\hline & 6 Month & 33 & 1.17 & 0.01 & 0.58 & - & 0.36 & 0.02 & -0.97 & 0.567 \\
\hline & 9 Month & 27 & 1.21 & 0.07 & 0.53 & - & 0.35 & 0.19 & -1.12 & 0.565 \\
\hline & 12 Month & 20 & 1.08 & 0.09 & 0.46 & 0.12 & 0.33 & 0.30 & -1.45 & 0.507 \\
\hline
\end{tabular}

As shown in Table 3, when the duration of drought becomes longer (3 Month to Month 12), number of events and median values of drought intensity were reduced but averages of drought intensities were found in same drought class "near normal". The calculated percentages of event number and drought classes (McKee et al., 1995) were given in Table 4.

Regarding the percent of event number it was seen that the most of the percentages $(67 \%-72 \%)$ for all SPI values were in the near normal class. In the previous studies drought intensity of Marmara Region was found as maximum "1" (Sırdaş, 2002). Drought intensities of Bursa were determined close to Marmara Region in this study. 
Table 4. The calculated percentages of event number and drought classes

\begin{tabular}{c|c|c|c|c|c}
\hline \multirow{2}{*}{ SPI Values } & \multirow{2}{*}{ Class } & 3 Month & 6 Month & 9 Month & 12 Month \\
\cline { 2 - 6 } & & \multicolumn{4}{|c}{$\mathbf{( \% )}$} \\
\hline$>2$ & Extremely wet & 4.857 & 3.077 & 2.250 & 5.176 \\
$1.5-1.99$ & Very wet & 6.071 & 5.385 & 2.750 & 3.765 \\
$1.0-1.49$ & Moderately wet & 21.250 & 13.846 & 8.750 & 11.765 \\
$-\mathbf{0 . 9 9}$ to $\mathbf{0 . 9 9}$ & Near normal & $\mathbf{7 0 . 1 3 7}$ & $\mathbf{6 7 . 6 8 0}$ & $\mathbf{6 7 . 4 0 9}$ & $\mathbf{7 1 . 9 1 0}$ \\
-1 to -1.49 & Moderately dry & 7.671 & 10.773 & 12.256 & 9.551 \\
-1.5 to -1.99 & Severely dry & 4.658 & 4.144 & 3.064 & 4.494 \\
$<-2$ & Extremely dry & 3.014 & 1.381 & 1.950 & 1.685 \\
\hline
\end{tabular}

\section{The effect of neural network structure on performance function (MSE) and model estimation power $(R)$}

The effect of neural network structure by changing of inputs, outputs and number of hidden neurons (layer) on model performance was investigated. Mean Square Error (MSE) has been adopted as a measure of performance (as performance function) for comparing the effectiveness of tested structures (Belayneh et al., 2016; Lalahem and Hani, 2017). The performance function (MSE) values and correlation coefficients (R) obtained for training, validation, testing and whole data sets. The model structures and their performance functions (MSE) values and correlation coefficients (R) of the data sets are presented in Table 5.

In the first model, air temperatures ( 3 parameters), global insolutions ( 2 parameters) and total precipitation were chosen as inputs also twin soil temperature parameters were chosen as outputs. This model was run quite efficiently.

In the second model air temperatures (3 parameters), soil temperatures (2 parameters), global insolations (2 parameters) and monthly average relative humidity (\%) were inputs and monthly total precipitation $(\mathrm{mm})$ was the output parameter. The calculation of MSE values of model 2 resulted in large numbers while correlation coefficients $(\mathrm{R})$ were found little higher than in the other models. Therefore, modelling the precipitation from the meteorological parameters was possible with some error and this model run was not quite efficient.

In model 3 and model 4, modelling the SPI 12 from SPI 3 and SPI 9 was very efficient and also with increasing of hidden layer number in model 4 the model worked better than model 3. In model $4 \mathrm{MSE}$ values of training and validation stages were decreased and correlation coefficient $(\mathrm{R})$ of whole data was increased.

Increasing of input numbers in model 5 and model 6 (3, 6 and 9 months SPI) led to more efficient modelling than model 3 and model 4 . $R$ values were increased and MSE values were decreased in model 5 and 6 . When model 5 compared to model 6 , rising of hidden layer in model 6 was ensured more efficiently than in model 5.

As a result, it was found that all of the 5 models were successfully except model 2 . R and MSE values calculated were in the acceptable range (Sinha and Das, 2015; Yonar and Yalili Kilic, 2014). MSE values in this study were found smaller than some water quality studies (Chen et al., 2014). This showed that hydrological and meteorological parameters were modeled well with ANN (Daliakopoulos and Tsanis, 2016; Sušanj et al., 2016; Sayagavi and Charhate, 2017). But in some water pollution and quality studies when number of data and tests were increased MSE values were calculated 
smaller (Sinha and Das, 2015; Yonar and Yalili Kilic, 2014). It was revealed in this study that precipitations in connection with meteorological drought were modeled better with SPI values. In the other studies SPI values were modeled well with neural network and Neural-based Fuzzy Inference System too (Ibrahimi and Baali, 2017; Belayneh et al., 2016). Also some modelling studies about the other drought indices (e.g. Effective Drought Index -EDI) gave good results (Pedro-Monzonís et al., 2015). Figures 5 and 6 display the observed time series and forecasted values with the model structures. In addition, the corresponding scatter plots were also presented.
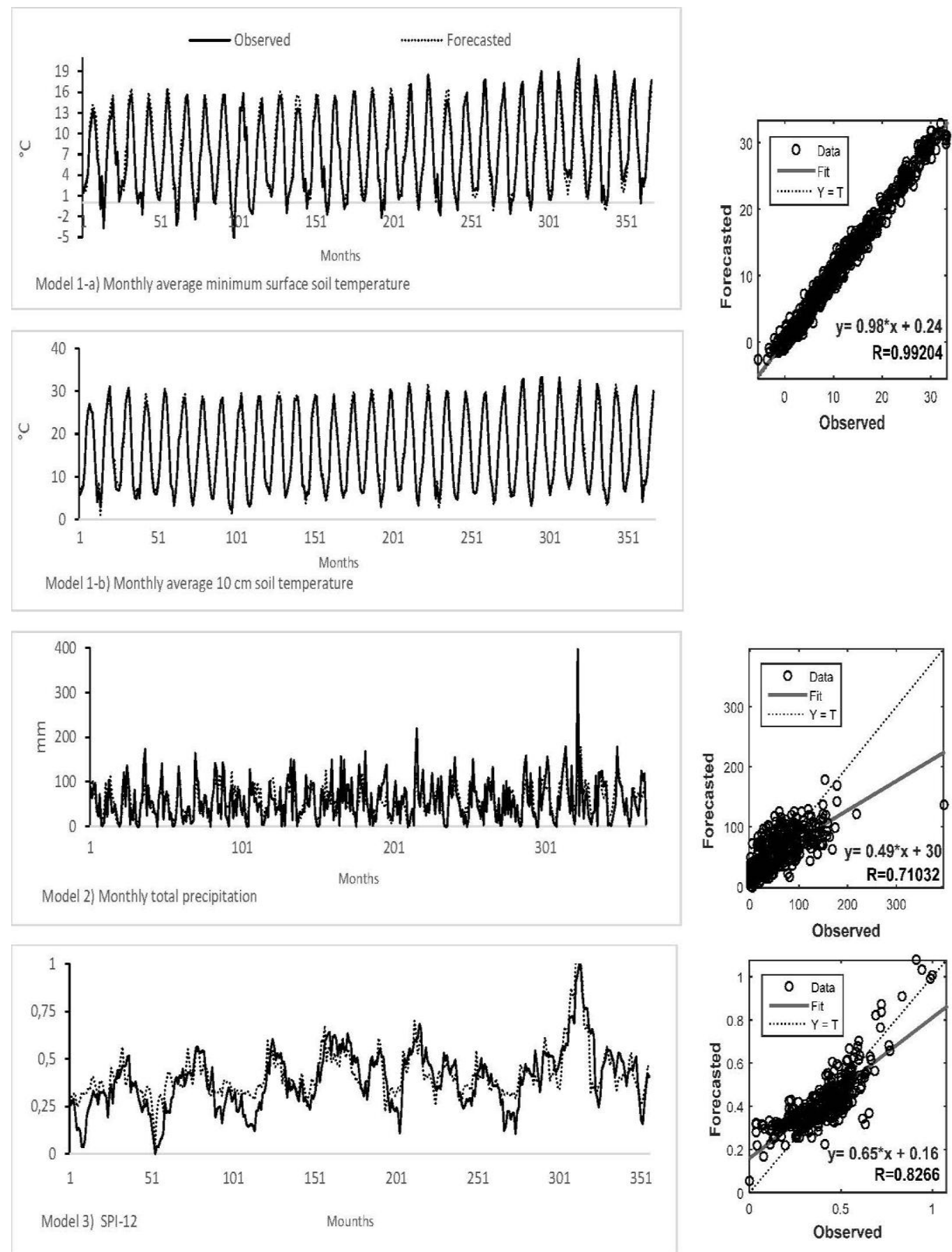

Figure 5. Time series of observed and forecasted values with the model structures and the corresponding scatter plots 

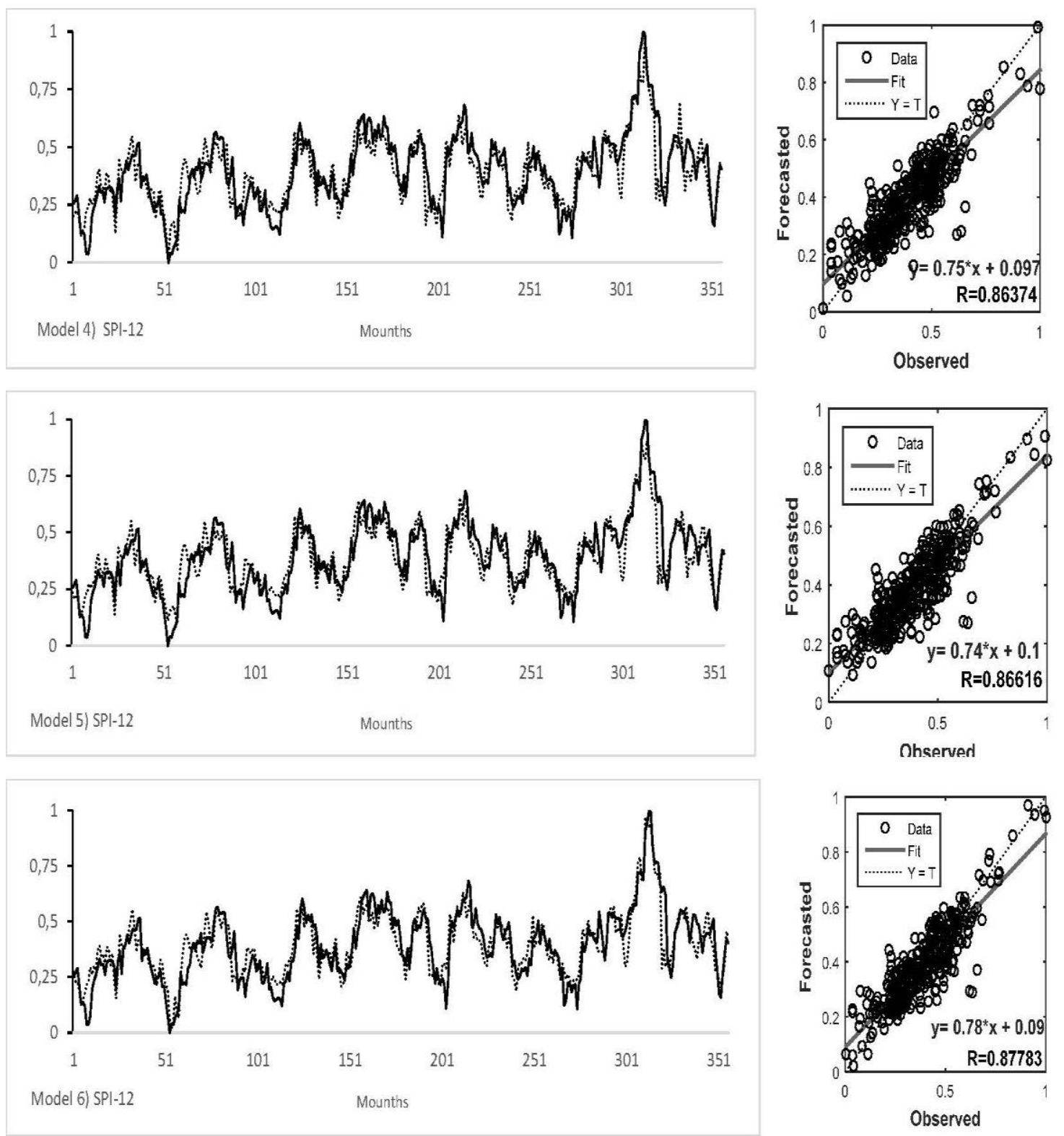

Figure 6. Time series of observed and forecasted values with the model structures and the corresponding scatter plots (continued)

\section{Conclusion}

Drought is a climate element that has devastating consequences on national economy and public life and Turkey is located in the semi-arid region. Therefore, monitoring and precautions for drought species are crucial.

In this study, time series of the Standardized Precipitation Index (SPI) are constructed for different periods based on monthly mean precipitation values, to determine drought categories. It was determined that the most of the percentages (67$72 \%)$ for all SPI values $(3,6,9,12$ months) was in the near normal class close to Marmara Region-Turkey.

Not only benefiting from the precipitation series, other meteorological variables were also used for examination of drought. If precipitation data is absent, it is not possible to 
account for the drought index. Therefore, soil temperatures in Bursa City-Turkey as an indicator of agricultural and meteorological droughts were simulated with ANN model in this study. In addition, total precipitation and 12 month Standard Precipitation Index (SPI-12) parameters were also simulated with Artificial Neural Network Model had different structures.

Table 5. The model structures and their performance functions (MSE) values and correlation coefficients $(R)$ of the data sets

\begin{tabular}{|c|c|c|c|c|c|c|c|c|c|c|}
\hline \multirow[b]{2}{*}{$\begin{array}{l}\text { Model } \\
\text { No }\end{array}$} & \multirow[b]{2}{*}{ Inputs } & \multirow[b]{2}{*}{ Outputs } & \multirow[b]{2}{*}{ ANN } & \multicolumn{3}{|c|}{ MSE } & \multicolumn{4}{|c|}{$\mathbf{R}$} \\
\hline & & & & Training & Validation & Testing & Training & Validation & Testing & $\begin{array}{c}\text { Whole } \\
\text { data set }\end{array}$ \\
\hline $\begin{array}{c}\text { Model } \\
1\end{array}$ & $\begin{array}{c}\text { Monthly average air } \\
\text { temperature }\left({ }^{\circ} \mathrm{C}\right) \\
\text { Monthly average } \\
\text { maximum air } \\
\text { temperature }\left({ }^{\circ} \mathrm{C}\right) \\
\text { Monthly average } \\
\text { minimum air temperature } \\
\left({ }^{\circ} \mathrm{C}\right) \\
\text { Monthly total global } \\
\text { insolation intensity } \\
\left(\mathrm{cal} / \mathrm{cm}^{2}\right) \\
\text { Monthly average-Daily } \\
\text { total global insolation } \\
\text { intensity }\left(\mathrm{cal} / \mathrm{cm}^{2}\right) \\
\text { Monthly total } \\
\text { precipitation }(\mathrm{mm}) \\
\end{array}$ & \begin{tabular}{|c|} 
\\
a) Monthly \\
average \\
minimum \\
surface soil \\
temperature $\left({ }^{\circ} \mathrm{C}\right)$ \\
\\
b) Monthly \\
average $10 \mathrm{~cm}$ \\
soil temperature \\
$\left({ }^{\circ} \mathrm{C}\right)$
\end{tabular} & $6-1-2$ & 1.3091 & 1.0263 & 0.8606 & 0.9917 & 0.9928 & 0.9945 & 0.99204 \\
\hline $\begin{array}{c}\text { Model } \\
2\end{array}$ & $\begin{array}{c}\text { Monthly average air } \\
\text { temperature }\left({ }^{\circ} \mathrm{C}\right) \\
\text { Monthly average } \\
\text { maximum air } \\
\text { temperature }\left({ }^{\circ} \mathrm{C}\right) \\
\text { Monthly average } \\
\text { minimum air temperature } \\
\left({ }^{\circ} \mathrm{C}\right) \\
\text { Monthly average } \\
\text { minimum surface soil } \\
\text { temperature }\left({ }^{\circ} \mathrm{C}\right) \\
\text { Monthly average } 10 \mathrm{~cm} \\
\text { soil temperature }\left({ }^{\circ} \mathrm{C}\right) \\
\text { Monthly total global } \\
\text { insolation intensity } \\
\left(\mathrm{cal} / \mathrm{cm}^{2}\right) \\
\text { Monthly average-Daily } \\
\text { total global insolation } \\
\text { intensity }\left(\mathrm{cal} / \mathrm{cm}^{2}\right) \\
\text { Monthly average relative } \\
\text { humidity }(\%)\end{array}$ & $\begin{array}{l}\text { Monthly total } \\
\text { precipitation } \\
\text { (mm) }\end{array}$ & $8-1-1$ & 1192.0973 & 741.9998 & 1142.2332 & 0.6761 & 0.8199 & 0.7924 & 0.71032 \\
\hline $\begin{array}{c}\text { Model } \\
3\end{array}$ & $\begin{array}{l}\text { SPI-3 Month } \\
\text { SPI-9 Month }\end{array}$ & SPI-12 Month & $2-2-1$ & 0.0087 & 0.0068 & 0.0092 & 0.8262 & 0.7104 & 0.8832 & 0.8266 \\
\hline $\begin{array}{c}\text { Model } \\
4\end{array}$ & $\begin{array}{l}\text { SPI-3 Month } \\
\text { SPI-9 Month } \\
\end{array}$ & SPI-12 Month & $2-5-1$ & 0.0062 & 0.0050 & 0.0095 & 0.8657 & 0.8989 & 0.8488 & 0.86374 \\
\hline $\begin{array}{c}\text { Model } \\
5\end{array}$ & $\begin{array}{l}\text { SPI-3 Month } \\
\text { SPI-6 Month } \\
\text { SPI-9 Month }\end{array}$ & SPI-12 Month & $3-2-1$ & 0.0062 & 0.0084 & 0.0051 & 0.8644 & 0.7991 & 0.9192 & 0.86616 \\
\hline $\begin{array}{c}\text { Model } \\
6\end{array}$ & $\begin{array}{l}\text { SPI-3 Month } \\
\text { SPI-6 Month } \\
\text { SPI-9 Month }\end{array}$ & SPI-12 Month & $3-7-1$ & 0.0059 & 0.0076 & 0.0036 & 0.8841 & 0.8334 & 0.8714 & 0.87783 \\
\hline
\end{tabular}

It was confirmed that 5 models of the 6 models were successful except for model 2 . It was found that R and MSE values calculated were acceptable and rising of hidden 
layers and input numbers in the model structures were ensured efficiently. Modelling the precipitation from the meteorological parameters (Model 2) was possible with some error. For this reason, it was found that simulations of SPI-12 and soil temperatures were indicative to meteorological and agricultural droughts. Also this study showed that ANN was effective in forecasting the SPI and was effective tool for drought forecasting.

Finally, the developed ANN models were found to be suitable to make effective extreme point predictions. Drought predictions made by ANN models would be useful for local administrations and water resources planners. Hence, this paper presented an applicable approximation to this planning stage by means of the ANN modelling approach.

Acknowledgments. I would like to thank Environmental Engineer Tuncay BOZ for computer aids and his valuable research to improve the manuscript.

\section{REFERENCES}

[1] Anonymous (2014a): Drought Analysis. - Retrieved from Meteoroloji Genel Müdürlügü: http://www.mgm.gov.tr/veridegerlendirme/kuraklik-analizi.aspx?d=yontemsinif.

[2] Anonymous (2014b): Adrese Dayalı Nüfus Kayıt Sistemi Sonuçları. - Retrieved from http://www.tuik.gov.tr/PreHaberBultenleri.do?id=18616.

[3] Anonymous (2014c): Bursa İlindeki Gözlem Şebekemiz. - Retrieved on 11.05.2014, from Meteoroloji 3. Bölge Müdürliğü.

[4] Anonymous (2016a): Handbook of Drought Indicators and Indices. - World Meteorological Organization (WMO), Global Water Partnership (GWP), The National Drought Mitigation Center (NDMC).

[5] Anonymous (2016b): Standardized Precipitation Index - Micronesia and Samoa data. Retrieved from NOAA's National Climatic Data Center: https://www.ncdc.noaa.gov/monitoring-content/sotc/drought/2016/07/noaa-nws-hnl-spitable-micronesia-samoa-jul16.pdf.

[6] Belayneh, A., Adamowski, J., Khalil, B. (2016): Short-term SPI drought forecasting in the Awash River Basin in Ethiopia using wavelet transforms and machine learning methods. - Sustainable Water Resources Management 2(1): 87-101.

[7] Berhan, G., Tadesse, T., Atnafu, S. (2015): Drought spatial object prediction approach using artificial neural network. - Geoinformatics and Geostatistics: An Overview 3: 2.

[8] Buttafuoco, G., Caloiero, C. (2014): Drought events at different timescales in southern Italy (Calabria). - Journal of Maps 10(4): 529-537.

[9] Boz, T. (2015): Bursa İli Meteorolojik Kuraklık Durumunun Değerlendirilmesi. - Bitirme Projesi, Uludağ Üniversitesi, Mühendislik Fakültesi, Bursa.

[10] Buttafuoco, G., Caloiero, T. (2014): Drought events at different timescales in southern Italy (Calabria). - Journal of Maps 10(4): 529-537.

[11] Chen, J. F., Hsieh, H. N., Do, Q. H. (2014): Forecasting Hoabinh Reservoir's incoming flow: an application of neural networks with the Cuckoo search algorithm. - Information 5: 570-586.

[12] Chen, W., Liu, W., Huang, W., Liu, H. (2017): Prediction of salinity variations in a tidal estuary using artificial neural network a three-dimensional hydrodynamic models. Computational Water, Energy, and Environmental Engineering 6(1): 107-128.

[13] Cömert, Z., Kocamaz, A. F. (2017): A study of artificial neural network training algorithms for classification of cardiotocography signals. - Journal of Science and Technology 7(2): 93-103. 
[14] Daliakopoulos, I. N., Tsanis, I. K. (2016): Comparison of an artificial neural network and a conceptual rainfall-runoff model in the simulation of ephemeral streamflow. Hydrological Sciences Journal 61(15): 2763-2774.

[15] Deo, R., Byun, H. R., Adamowski, J. F., Begum, K. (2015): Application of effective drought index for quantification of meteorological drought events: a case study in Australia. - Theoretical and Applied Climatology 122(3-4). DOI: 10.1007/s00704-0151706-5.

[16] Gürler, Ç. (2017): Evaluation of Hydrological drought with the standardized Indis in Beyşehir and Konya-Çumra-Karapinar Subbasins (in Turkish). - Expertise Thesis, Ministry of Forestry and Water General Directorate of Water Management, Ankara.

[17] IPCC (2014): Climate Change 2014: Synthesis Report Summary for Policymakers. Working Groups of the Intergovernmental Panel on Climate Change (IPCC), climate Change As the Final Part of the IPCC's Fifth Assessment Report (AR5).

[18] Ibrahimi, A. E., Baali, A. (2017): Application of neural modeling and the SPI index for the prediction of weather drought in the Saïss Plain (Northern Morocco). - International Journal of Intelligent Engineering and Systems 10(5): 1-10.

[19] Kurnaz, L. (2014): Drought in Turkey. - Istanbul Policy Center, Sabancı University and Stiftung Mecator Initiative Policy Brief, İstanbul.

[20] Łabędzki, L., Bak, B. (2014): Meteorological and agricultural drought indices used in drought monitoring in Poland: a review. - Meteorology Hydrology and Water Management - Research and Operational Application 2(2): 3-13.

[21] Lallahem, S., Hani, A. (2017): Artificial neural networks for defining the water quality determinants of groundwater abstraction in coastal aquifer. - Technologies and Materials for Renewable Energy, Environment and Sustainability AIP Conf. Proc. AIP Publishing, Melville, NY.

[22] Lima, G. R. T., Santos, L. B. L., Carvalho, T. J., Carvalho, A. R., Cortivo, F. D., Scofield, G. B., Negri, R. G. (2016): An operational dynamical neuro-forecasting model for hydrological disasters. - Modeling Earth Systems and Environment 2(94): 2-9.

[23] MATLAB (2015): Getting Started Guide R2015b. - Retrieved from www.mathworks.com.

[24] McKee, T., Doesken, N., Kleist, J. (1993): The relationship of drought frequency and duration to time scales. - Eight Conference on Applied Climatology, January 12-17, pp. 179-184.

[25] Mckee, T., Doesken, N., Kleist, J. (1995): Drought monitoring with multiple time scales. - Proceeding of The 9th Conference on Applied Climatology, pp. 233-236. American Meteorological Society, Boston.

[26] Milanović, M., Gocić, M., Trajković, S. (2014): Analysis of Meteorological and Agricultural Droughts in Serbia. - Architecture and Civil Engineering 12(3): 253-264.

[27] Nawi, N. M., Rehman, M. Z., Hafifie, N., Khan, A., Siming, I. A. (2016): Bat-Bp: a new bat based back-propagation algorithm for efficient data classification. - Journal of Engineering and Applied Sciences 11(24): 14048-14051.

[28] NOAA (2017): What's the difference between global warming and climate change? National Oceanic and Atmospheric Administration. https://www.climate.gov/newsfeatures/climate-qa/whats-difference-between-global-warming-and-climate-change.

[29] Pablos, M., Martínez-Fernández, J., Sánchez, N., González-Zamora, A. (2017): Temporal and spatial comparison of agricultural drought indices from moderate resolution satellite soil moisture data over Northwest Spain. - Remote Sensing 9(11): 2-27.

[30] Pedro-Monzonís, M., Solera, A., Ferrer, J., Estrela, T., Paredes-Arquiola, J. (2015): A review of water scarcity and drought indexes in water resources planning and management. - Journal of Hydrology 527: 482-493. 
[31] Salami, E. S., Ehteshami, M. (2016): Application of neural networks modeling to environmentally global climate change at San Joaquin Old River Station. - Modeling Earth Systems and Environment 2(38): 2-9.

[32] Sayagavi, V., Charhate, S. (2017): Applications of soft tools to solve hydrological problems for an integrated Indian catchment. - International Journal of Water Resources and Environmental Engineering 9(7): 150-161.

[33] Sirdaş, S. (2002): Meteorological Drought Modeling and Application to Turkey (in Turkish). - Ph.D. Thesis, Istanbul Technical University, Institute of Science and Technology, Istanbul.

[34] Sinha, K., Das, P. (2015): Assessment of water quality index using cluster analysis and artificial neural network modeling: a case study of the Hooghly River basin, West Bengal, India. - Desalination and Water Treatment 54(1): 28-36.

[35] Sun, P., Zhang, Q., Wen, Q., Singh, V., Shi, P. (2017): Multisource data-based integrated agricultural drought monitoring in the Huai River basin, China. - Journal of Geophysical Research: Atmospheres 122(10): 751-772.

[36] Sušanj, I., Ozanic, N., Marovic, I. (2016): Methodology for developing hydrological models based on an artificial neural network to establish an early warning system in small catchments. - Advances in Meteorology ID 9125219.

[37] Wen, L., Macdonald, R., Morrison, T., Hameed, T., Saintilan, N., Ling, J. (2013): From hydrodynamic to hydrological modelling: Investigating long-term hydrological regimes of key wetlands in the Macquarie Marshes, a semi-arid lowland floodplain in Australia. Journal of Hydrology 500: 45-61.

[38] Yang, L., Qian, F., Song, D., Zheng, K. (2016): Research on Urban Heat-island Effect. Procedia Engineering 4th International Conference on Countermeasures to Urban Heat Island (UHI) 2016: 169: 11-18.

[39] Yonar, T., Yalıl1, M. (2014): Oxygen demand and color removal from textile wastewater by UV/H2O2 using artificial neural networks. - Water Environment Research 86(11): 2159-2165. 